Hydrol. Earth Syst. Sci., 16, 3783-3790, 2012

www.hydrol-earth-syst-sci.net/16/3783/2012/

doi:10.5194/hess-16-3783-2012

(C) Author(s) 2012. CC Attribution 3.0 License.

(c) (i)

\title{
Morphology of Tigris River within Baghdad City
}

\author{
A. A. Ali, N. A. Al-Ansari, and S. Knutsson \\ Department of Civil, Environmental and Natural Resources Engineering, Lulea University of Technology, Sweden
}

Correspondence to: A. A. Ali (ammar.ali@ltu.se)

Received: 12 March 2012 - Published in Hydrol. Earth Syst. Sci. Discuss.: 2 May 2012

Revised: 19 September 2012 - Accepted: 24 September 2012 - Published: 25 October 2012

\begin{abstract}
In recent years, substantial changes have occurred in the morphology of the River Tigris within Baghdad City. Although huge volumes of sediment are being trapped in recently constructed headwater reservoirs, the number of islands in the Tigris at Baghdad is increasing. The debris of bridges destroyed in the wars of 1991 and 2003 and their subsequent reconstruction have enhanced the development of these islands. As a consequence the ability of the river to carry the peaks of flood waters has been reduced. This has led to potential increase of flooding in parts of the city.

The bed of the River Tigris has been surveyed on three occasions (1976, 1991, and 2008). The most recent survey was conducted by the Ministry of Water Resources, extended $49 \mathrm{~km}$ from the Al-Muthana Bridge north Baghdad to the confluence with the Diyala River south Baghdad. It yielded cross-section profiles at $250 \mathrm{~m}$ intervals. The data are used to predict the maximum flood capacity for the river using the one-dimensional hydraulic model for steady flow "HECRAS" modeling. Calibration of the model was carried out using field measurements for water levels along the last $15 \mathrm{~km}$ of the reach and the last $10 \mathrm{yr}$ of observation at the Sarai Baghdad gauging station.

The model showed a significant predicted reduction in the current river capacity below that which the river had carried during the floods of 1971 and 1988. The three surveys conducted on the same reach of the Tigris indicated that the ability of the river to transport water has decreased.
\end{abstract}

\section{Introduction}

The River Tigris is $1850 \mathrm{~km}$ in length, rising in the Taunus Mountains of Eastern Turkey. The river flows for about $400 \mathrm{~km}$ through Turkey before entering Iraq. The total length of the river in Iraq is $1418 \mathrm{~km}$. It drains an area of
$473103 \mathrm{~km}^{2}$ which is shared by Turkey, Syria and Iraq, as shown in Fig. 1. About $58 \%$ of the basin lies in Iraq, and no major tributary joins the Tigris south of Baghdad (Al-Ansari et al., 1986, 1987), but several canals draw water from the Tigris in this region for irrigation purposes. For this reason the mean annual daily flow of the river falls below the discharge at Baghdad $\left(1140 \mathrm{~m}^{3} \mathrm{~s}^{-1}\right)$ at Kut and Amara, cities to the south.

The average annual flow discharge of the Tigris is $21.2 \mathrm{~km}^{3} \mathrm{yr}^{-1}\left(672 \mathrm{~m}^{3} \mathrm{~s}^{-1}\right)$ when it enters Iraq. Its main tributaries contribute a further $24.78 \mathrm{~km}^{3} \mathrm{yr}^{-1}\left(786 \mathrm{~m}^{3} \mathrm{~s}^{-1}\right)$ of water and some minor wadies from Iran carry about $7 \mathrm{~km}^{3} \mathrm{yr}^{-1}\left(222 \mathrm{~m}^{3} \mathrm{~s}^{-1}\right)$ directly into the southern marsh area (Al-Ansari and Knutsson, 2011).

Several cities have been built on the banks of the Tigris since the dawn of civilization. Among these is Baghdad, the capital city of Iraq. Parts of all of these cities (Mosul, Samara, Baghdad and Al-Kut) were inundated by the spring floods of the river in 1954, 1971 and 1988. To overcome this problem, various hydraulic projects have been constructed along the Tigris and its tributaries in Mosul, Samara, Dokan and Darbandikhan. The control of the river was most efficient during the twentieth century, after huge dams were built to entrap some of the waters (Al-Ansari and Knutsson, 2011). Despite the presence of many hydraulic structures upstream of the city, parts of Baghdad were inundated in 1988. For this reason the Ministry of Water Resources, which had conducted a previous survey of the river in 1976, undertook a second survey in 1991. In 2008 the Ministry of Water Resources made a third survey, extending from the Al-Muthana Bridge north of Baghdad to the Tigris-Diyala confluence in the south using land surveying instrument (total station) and echo sounder.

In the last century, the nature of the successions of high water and flood conditions and the interactions of the flows with the many control structures have induced erosion and 


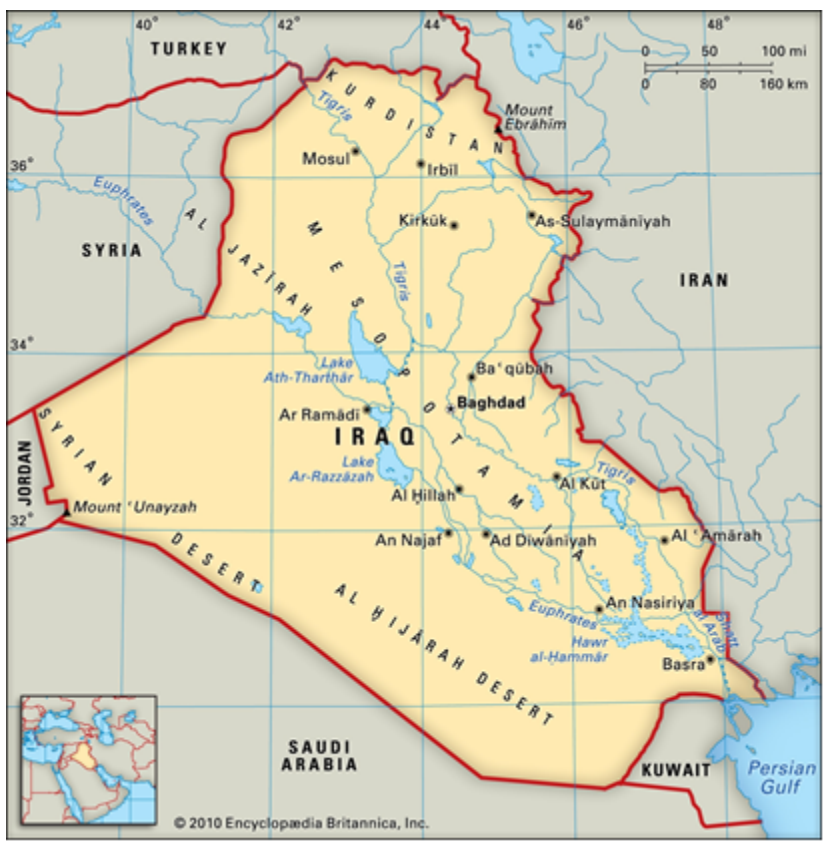

Fig. 1. Map of Iraq showing the Tigris and Euphrates Rivers (Encyclopaedia Britannica, 2010).

deposition of material on the river bed, as well as the growth and disappearance of islands, to the extent that is has been classified as an unstable river (Geohydraulique, 1977).

During the last twenty years growing islands have become noticeable features in the Tigris channel within Baghdad City, the numbers of islands increasing with time. In this contribution the impact of human activities in dam building, bank lining and dumping of debris within the channel at Baghdad has led to changes in the geometry of the river and its ability to carry flood waters.

\section{Discharge of Tigris River for the period 1990-2010}

Water flows of the Tigris and Euphrates Rivers entering Iraq have decreased annually in a dramatic way for the past two decades, due to the major water impoundment projects constructed; some remain under construction on these rivers in the neighboring countries, Turkey, Syria and Iran (Al-Ansari and Knutsson, 2011). In addition, the problem has become more severe due to the recent dry climatic period in Iraq. As a result the flow of the Tigris at Baghdad has fallen sharply (about 19\% the trend of fall line according to the discharge values mentioned by Al-Shahrabaly, 2008). The average monthly discharge of the Tigris at Baghdad during the period 1960-2010 is shown in Fig. 2. Twenty years average discharge $\left(671 \mathrm{~m}^{3} \mathrm{~s}^{-1}\right)$ decreased to $\left(531 \mathrm{~m}^{3} \mathrm{~s}^{-1}\right)$ during 2000-2010 and it is less than half of the mean daily discharge of $1140 \mathrm{~m}^{3} \mathrm{~s}^{-1}$ prior to 2005 and well below the flood discharges of 4480, 3050 and $1315 \mathrm{~m}^{3} \mathrm{~s}^{-1}$ recorded in 1971, 1988 and 2005 respectively.

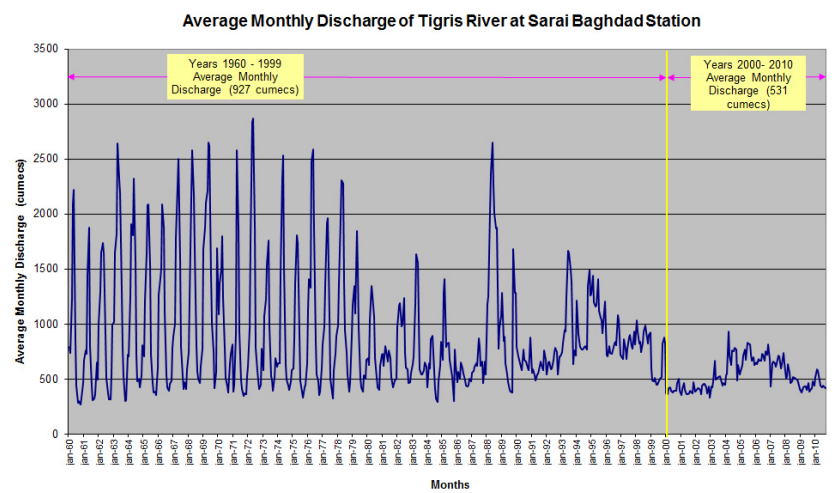

Fig. 2. Recorded Tigris River flow at Sarai Baghdad station for the period 1990-2010. Data source: Al-Shahrabaly (2008).

\section{Previous studies}

In the past, several studies have been conducted on the River Tigris. Among these NEDECO (1958) and Herza (1963) examined the hydraulic conditions controlling flows and the hydrological constraints, respectively. Later studies conducted by the Ministry of Irrigation were more related to the present research. The "Tigris River training project within Baghdad City" in 1977 was conducted with Geohydraulique, and a second study, in 1992, was linked with the University of Technology in Iraq. Suspended sediment samples were collected in both programs which were designed to improve the river channel by protecting the banks against water erosion in floods and raising the banks in places of expected overflow. The numerical models used in these investigations were for 1-D steady state flow (using a standard step technique) and also a morphological model for the river meanderings.

Similar river training studies have been conducted on many rivers worldwide. Marchi et al. (1996) evaluated river training works in the lower Po River of Italy. There, training activities had successfully reduced the overflow frequency as a consequence of protection and regulation works on the tributaries and also on the main river. The storage capacity of the river bed in flood was reduced due to a reduction of flood expansion areas in the upper and middle parts of the drainage basin.

Lammersen et al. (2002) investigated the impact of river training and retention measures on the flood peaks on the River Rhine in Germany. They found that weirs constructed along the upper reaches and other retention measures had successfully influenced the flood conditions along the river. The SYNHP hydrological model was used to describe the flood routing processes in the river by using single linear stores and this was used to evaluate the effects of retention measures in the upper reaches. The 1-D river flow model SOBEK was used to perform flow calculations for the middle and lower reaches, based on the Saint-Venant equations. 


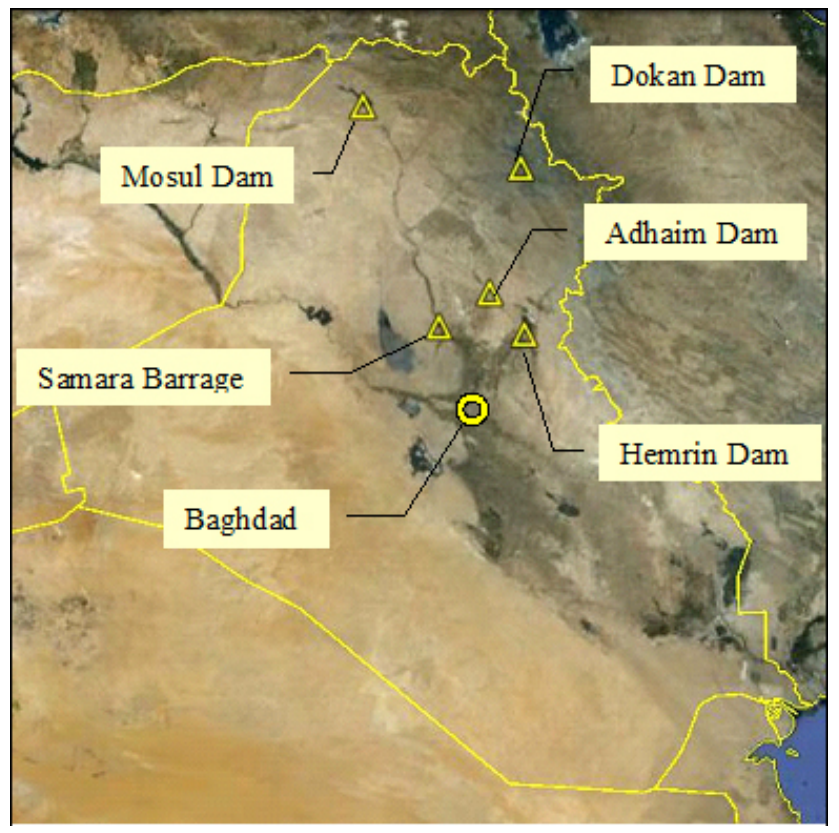

Fig. 3. Location of control structures upstream Baghdad City.

The models indicated that the river training activities led to an increase in peak flow.

Korpak (2007) demonstrated the influence of river training on channel erosion in Polish Mountain Rivers. Using data from $53 \mathrm{yr}$ of observations, he showed that debris dams and groynes built before 1980 had caused great changes in channel patterns and increased the channel gradient and the rate of river incision. He considered that although the measures to decrease river downcutting in alluvial deposits worked well, it had not been eliminated. Korpak noted that river training schemes distort the equilibrium of the channel systems and that most such projects were of limited success in the long term because they rarely considered the entire reaches of the rivers.

\section{Control structures upstream Baghdad City}

Four tributaries contribute to the Tigris River flows upstream of Baghdad (Fig. 1). A number of dams, barrages and regulators have been constructed on the river during and since the second half of the twentieth century (Fig. 3). To link these structures to the Tigris River surveys under examination, they can be classified according to three periods of installation. Prior to 1976 the Samara Barrage (1956) and the Dokan dam on the Lesser Zab tributary (1961) were the two main modifications to the river. During the second period, from 1976 to 1981, the Hemrin dam on the Diyala River has operated since 1981, and the Mosul dam on the Tigris began operating in 1986. The only significant major structure constructed since 1991 was the Adhaim dam, opened in 1999. No detail has been given for anticipated discharge of compensation waters

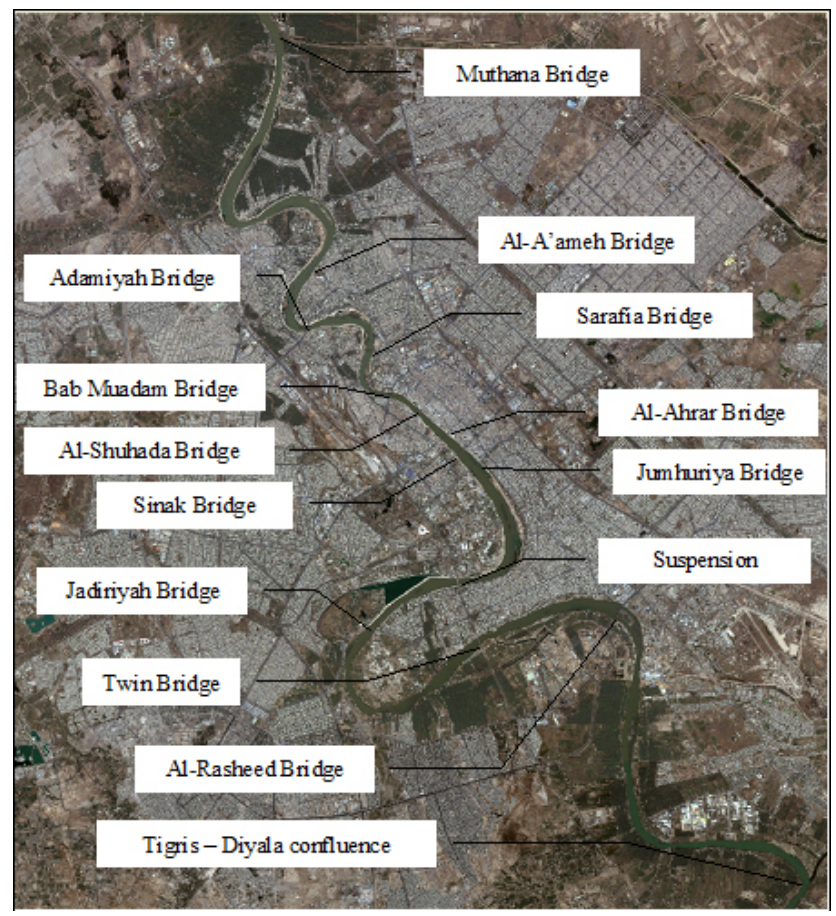

Fig. 4. The geographic distribution of the bridges in Baghdad City.

from the $10.4 \mathrm{~km}^{3}$ capacity reservoir to be created by the Ilisu dam in Turkey (yet to be completed) and their potential impact on the water movements in the middle Tigris valley area.

\section{Bridges on Tigris River within Baghdad City}

The City of Baghdad is divided into two substantial areas by the River Tigris. These are connected by a number of bridges which disturb the flow of the waters. Prior to 1976, six bridges spanned the river in the north of the city. Six more bridges were constructed during the period 1976 to 1991, four more in the north and two in the southern part of the city. Only one additional bridge has been constructed linking the southern parts of the city since 1991. The geographic distribution of the bridges (Fig. 4), with ten towards the north and only three in the south of the city indicates that the resulting disturbance to river flows is greater in the north than in the south.

During the wars of 1991 and 2003, three major bridges (Jumhuriya, Sarafia and the suspension bridge) suffered a high level of damage, causing large pieces of concrete and structural steel to fall into the river. Although some of the larger pieces (steel members) of debris were removed from the river bed, much of the smaller material (concrete fragments that spilt from the steel structure) could not be removed and remains on the river bed.

The reconstruction procedures for the three bridges required the installation of a temporary bridge for the 

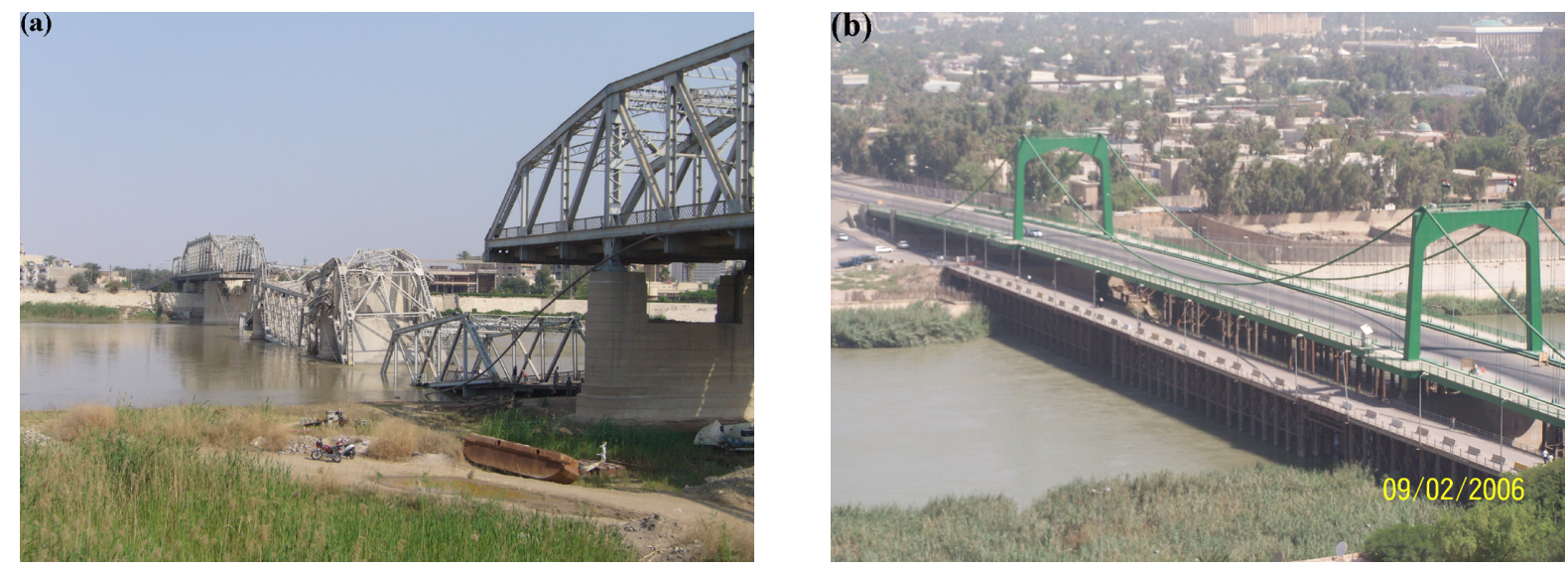

Fig. 5. (a) Destroyed parts from Al-Sarafia Bridge have fallen in the river (available at: www.wikipedia.org). (b) Temporary bridges parallel to the suspended bridge.

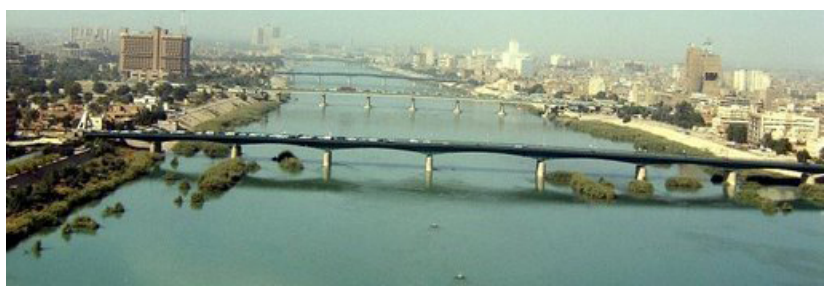

Fig. 6. Small growing islands at Jumhuriyah Bridge location.

suspension bridge and the formation of an earth structure capped by a roadway to carry heavy machinery in the case of the Sarafia Bridge. The damage to the Sarafia Bridge and the temporary bridges parallel to the suspended bridge are illustrated in Fig. 5. The construction and removal of these temporary structures are believed to have enhanced the formation of new islands in the river (Fig. 6).

\section{Changes in river geometry}

Three main islands were recognized in the 1976 survey, namely Suraidat (upstream the study reach), Um AlKhanazer and Abu Rumail (see Fig. 7, the dashed lines highlight the depositional side of the islands), and two smaller islands. The first, Kureat, lay in the second meander of the study reach and the second about $9 \mathrm{~km}$ upstream from the Diyala River confluence.

Between 1976 and 1991 a recreation park was constructed on Suraidat Island and an access connected it to the left bank of the river, creating a small lagoon. A similar development at Um Al-Khanazer Island linked it to the right bank, and likewise a lagoon was created beside that bank. The river cross-sections of the 1991 survey revealed changes in the bed and banks of the river and there were indications of new islands (in Abu Nuwas and Dura) growing which had not been

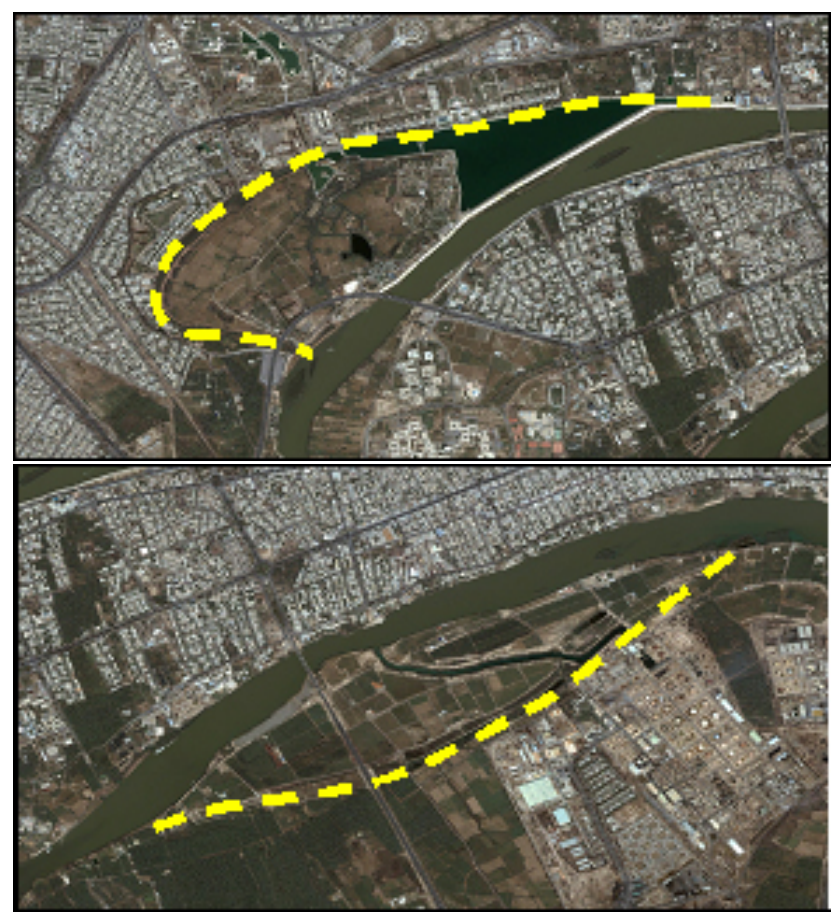

Fig. 7. Um Al-Khanazer and Abu Rumail islands after their right arms are deposit.

identified in the 1976 survey. These changes became more noticeable in the 2008 survey.

During the period 1976-1991 about $97 \%$ of the banks of the northern part of the river were subjected to artificial protection using rocks and concrete. The same was true in the southern part of the river, but to a lesser extent. By the end of 2002 about $66 \%$ of the banks of the reach had been protected to a level of 35-37 m above sea level in attempts to canalize the river course within the most populated areas and to avoid bank collapse during floods (Al-Ansari et al., 1979). 


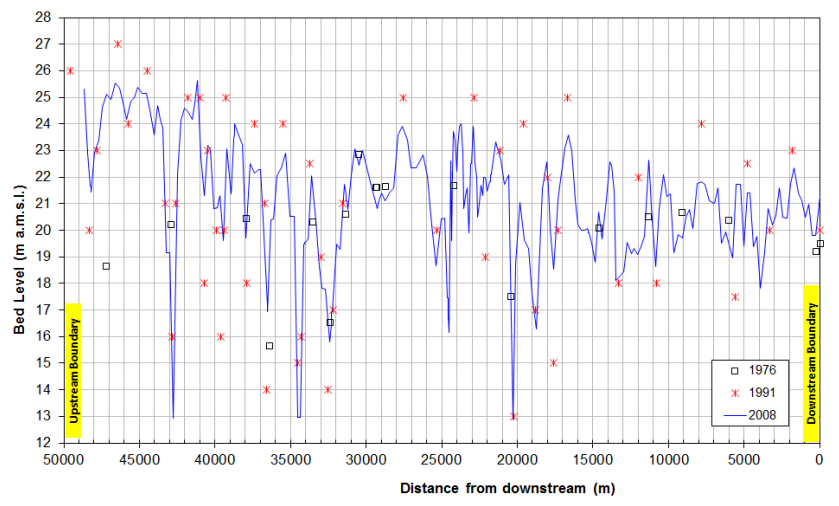

Fig. 8. Tigris River bed elevations during 1976, 1991 and 2008.

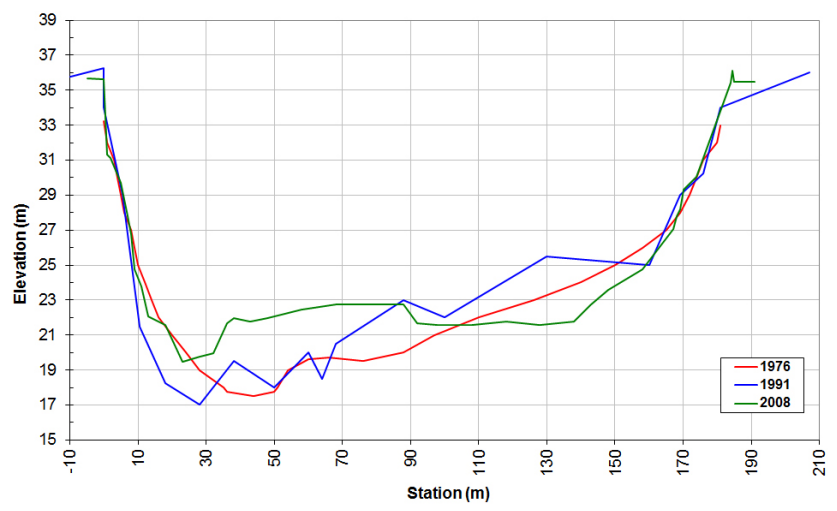

Fig. 9. Changing in geometry shape of Sarai Baghdad gauging station.

Seven samples of bed material were taken by van veen grab along $7 \mathrm{~km}$ in the northern part of the reach (between Al-A'ameh Bridge and AlShuhada' a Bridge) from the center line and on the quarters of transverse sections. The results of sieve analysis for three of the samples indicated that the major component is fine sand (finer than $0.3 \mathrm{~mm}$ diameter) as shown in Table 1. This is in agreement with Al-Ansari and Toma's (1984) description of the bed sediments of the River Tigris in Baghdad.

The irregularities in the cross-sections of the river reflect the variations in flow velocity controlling erosion or deposition in new parts of the reach. It is important to note that most of the suspended sediments formerly transported to the reach were now being trapped in the upstream reservoirs, so that the river was attempting to achieve a new stable regime (Morris and Fan, 2010).

The recent regional decrease in rainfall is leading to low water levels in the river reaches at Baghdad, and the waters are eroding only below the foundation levels of protection given to the upper banks. It is likely that this will lead to the collapse of parts of the protected banks in the future.

In addition to the variations in bed levels along the reach (Fig. 8), changes in elevation on any single cross section

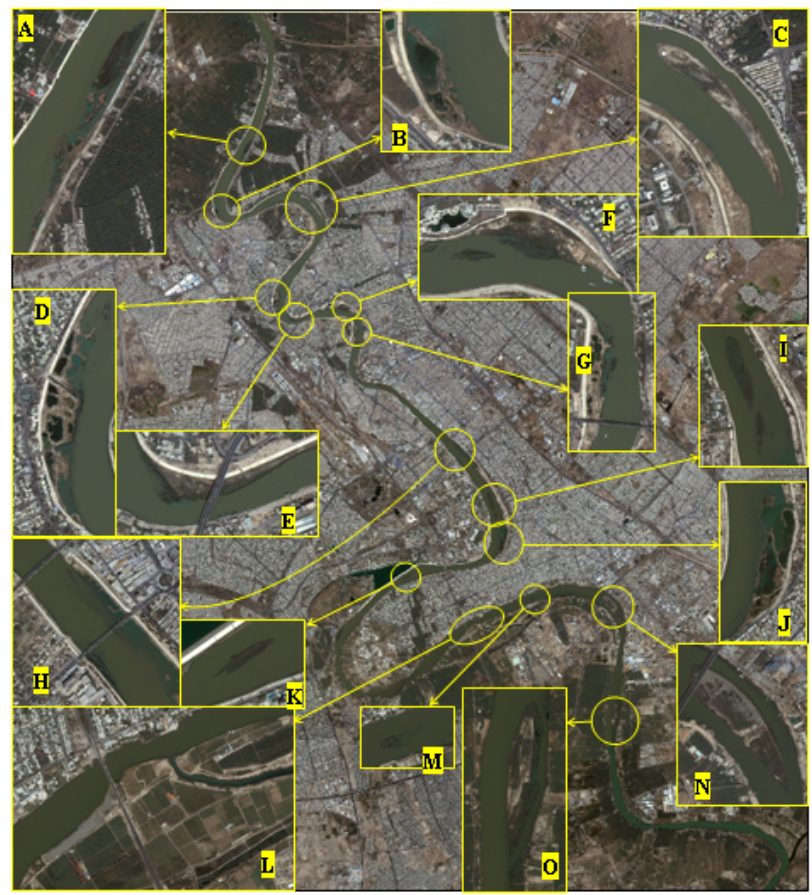

Fig. 10. Observed Obstacles in Tigris River in 2008.

Table 1. Components percentage of bed material samples for Tigris River in Baghdad City.

\begin{tabular}{lrrr}
\hline Location & Fine Sand & Silt & Clay \\
$\%$ & $\%$ & $\%$ \\
\hline Al-A'ameh - Adamiyah Bridges & 98 & 1.77 & 0.224 \\
Adamiyah - Sarafia Bridges & 95 & 4.87 & 0.13 \\
Sarafia - Bab Muadam Bridges & 85 & 11 & 4 \\
\hline
\end{tabular}

between the 1976, 1991 and 2008 surveys reached up to $4 \mathrm{~m}$ (Fig. 9). The 1991 cross-section showed the most extreme changes in bed level. This is believed to be due to the survey having been conducted shortly after the 1988 major floods. The bed level variation in 2008 was the least and may be attributed to the fact that the survey was conducted $20 \mathrm{yr}$ after the high flood of 1988 or alternatively was due to the river having suffered from low flow regime during the previous $20 \mathrm{yr}$.

The repeated surveys have shown that the average slope of the bed of the Tigris within Baghdad was substantially greater in $2008\left(5 \mathrm{~cm} \mathrm{~km}^{-1}\right)$ than in $1976\left(1.03 \mathrm{~cm} \mathrm{~km}^{-1}\right)$ and more than twice that in $1991\left(2.45 \mathrm{~cm} \mathrm{~km}^{-1}\right)$. The obstacles present in the river during the 2008 survey are listed in Table 2, with details of their location, length and type. Some are islands and others areas of bank accretion. Their positions are indicated in Fig. 10. 
Table 2. Main observed obstacles in Tigris River within Baghdad City in 2008.

\begin{tabular}{llrl}
\hline Location & Type & Length $(\mathrm{km})$ & Symbol (Fig. 10) \\
\hline Kura'at & Bank deposition & 1.4 & $\mathrm{~A}$ \\
Kadhmiyah & Bank deposition & 0.6 & $\mathrm{~B}$ \\
Kadhmiyah & Island & 1.0 & $\mathrm{C}$ \\
Kadhmiyah & Bank deposition & 1.2 & $\mathrm{D}$ \\
Adhmiyah & Bank deposition & 0.6 & $\mathrm{E}$ \\
Adhmiyah & Bank deposition & 0.8 & $\mathrm{~F}$ \\
Etiafiyah & Bank deposition & 0.7 & $\mathrm{G}$ \\
Sinak-Jumhuriyah & Small islands & - & $\mathrm{H}$ \\
Abu Nuwas1 & Island & 0.6 & $\mathrm{I}$ \\
Abu Nuwas2 & Island & 0.3 & \\
Abu Nuwas & Bank deposition & 1.0 & $\mathrm{~J}$ \\
Jadriyah & Island & 0.4 & $\mathrm{~K}$ \\
Dura & Bank deposition & 1.5 & $\mathrm{~L}$ \\
Dura & Island & 0.4 & $\mathrm{M}$ \\
Dura & Island & 1.0 & $\mathrm{~N}$ \\
Dura & Island & 1.1 & $\mathrm{O}$ \\
\hline
\end{tabular}

\section{Methodology}

\subsection{River geometry}

The survey conducted in the winter season of 2007-2008 by the Iraqi Ministry of Water Resources covered $49 \mathrm{~km}$ of the river, from the Al-Muthana Bridge in the north to the confluence with the Diyala River in the south. A total of 219 cross sections were surveyed at intervals of $250 \mathrm{~m}$ (some cross sections were conducted at lesser intervals especially at meanders), as shown in Fig. 11. The findings of this survey have been used in the present investigation to create a 1-D steady flow model, using the HEC-RAS program, with additional data on the locations and dimensions of the bridges.

\subsection{Boundary conditions}

The average discharge of the river at Baghdad calculated for the previous ten years and additional discharge figures considered in previous studies (Geohydraulique, 1977 and University of Technology, 1992) have been used in the model to define the upstream conditions, and a modified rating curve for the river below the Diyala confluence was used to define the downstream boundary for each of the upstream conditions.

\subsection{Model calibration}

Calibration of the model was achieved by using observed water level variations (59 observation points) along the lower $15 \mathrm{~km}$ of the studied reach on a single day when the discharge was $400 \mathrm{~m}^{3} \mathrm{~s}^{-1}$.

The problems of calibration were extended to an attempt to define suitable values for the Manning coefficients for the main channel and the flood plain. This was achieved by iteration to give coincidence between the computed water surface levels and those observed. The minimum Root Mean Square Errors (RSME) of $0.026 \mathrm{~m}$ were obtained for the coefficient

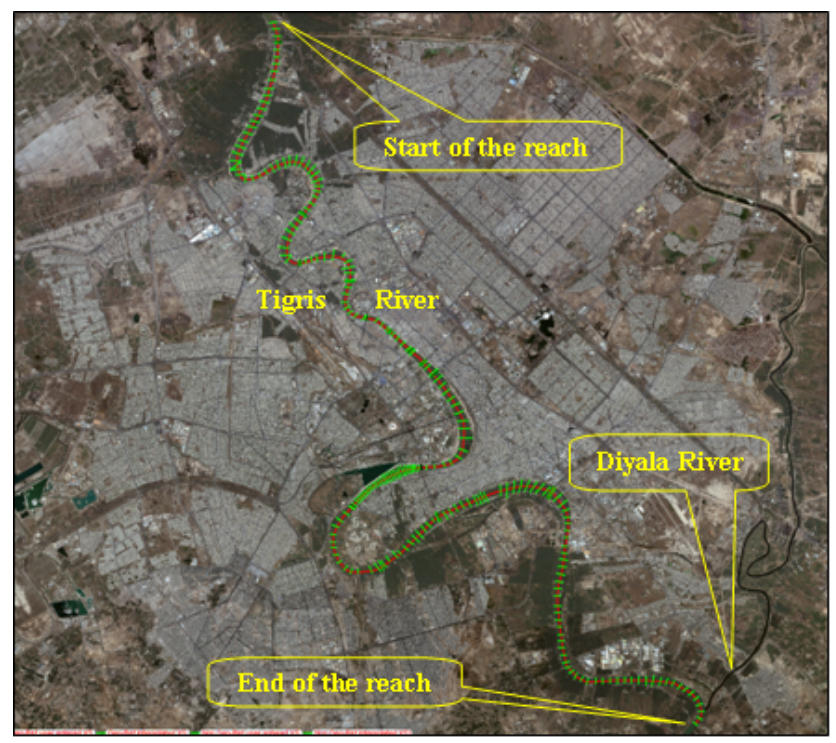

Fig. 11. Cross-sections of Tigris River by HEC-RAS.

values of 0.0285 for the main channel and 0.042 for the flood plains. No precise data for the water consumption through the reach were available and an estimate of the lateral inflow/outflow was included within the average inflow from the Diyala River of $5 \mathrm{~m}^{3} \mathrm{~s}^{-1}$.

\subsection{Model verification and application}

A range of different scenarios were examined by increasing the discharge, starting from the average flow for the previous ten years, in order to determine the critical discharge that can cause inundation. For some of these discharges (from 500 to $1300 \mathrm{~m}^{3} \mathrm{~s}^{-1}$ ), water surface levels had been recorded at the Sarai Baghdad station during that ten year period. A new RSME was computed for these observations giving good coincidence $(\mathrm{RSME}=0.046 \mathrm{~m})$ as shown in Fig. 12.

\section{Results and discussion}

The procedure of increasing upstream discharge was continued so that areas that had been inundated could be detected. The discharges that were considered in this work started at $500 \mathrm{~m}^{3} \mathrm{~s}^{-1}$ and increased in the same discharge steps as those considered in previous studies (Geohydraulique, 1977 and University of Technology, 1992). Each of these discharges was repeated in the model for four scenarios. The difference in each scenario was the lateral inflow represented by the Diyala River. The lateral inflow for the initial (base) scenario was $5 \mathrm{~m}^{3} \mathrm{~s}^{-1}$, which is the known average inflow observed in the Diyala, and it was also used for calibration purposes. The three other lateral inflows (taken from historical data for Diyala river) examined were 25,50 and $100 \mathrm{~m}^{3} \mathrm{~s}^{-1}$. The effect of the backwater curve associated with each lateral 


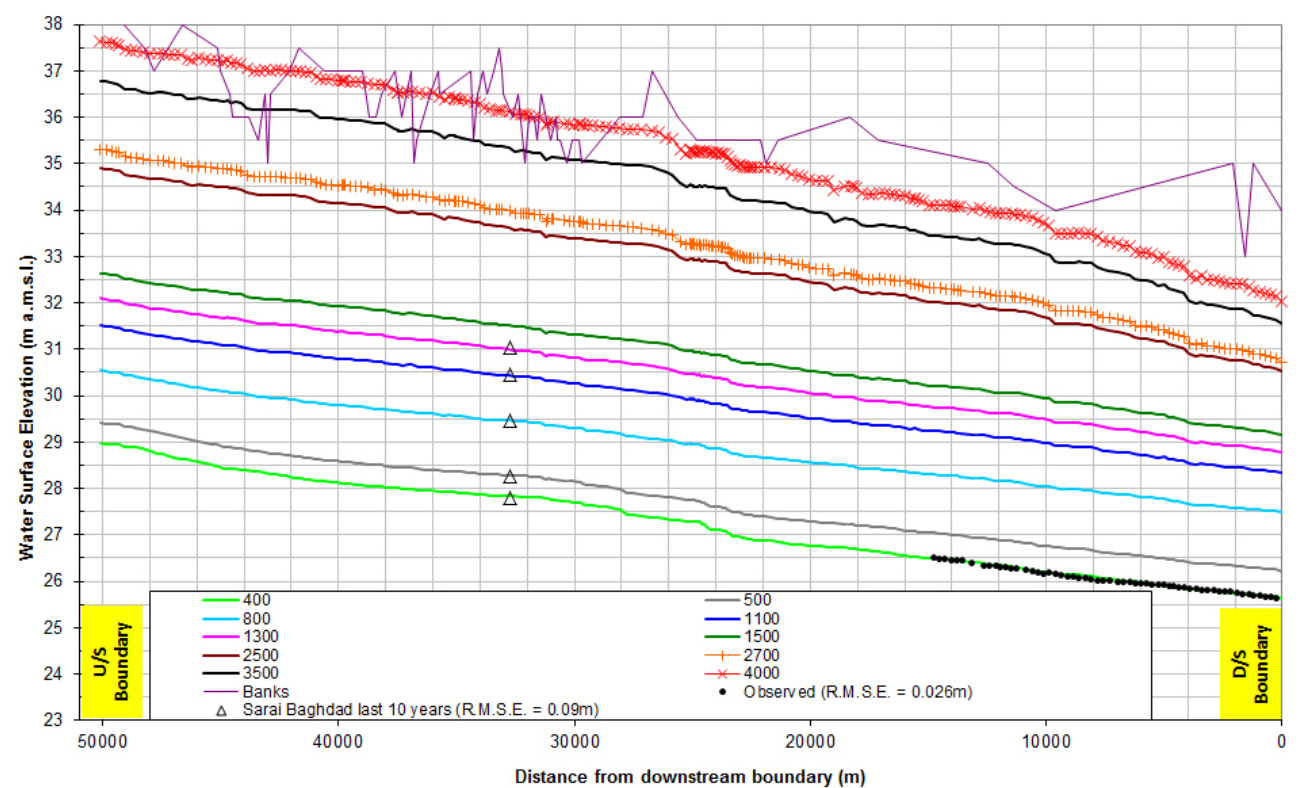

Fig. 12. Computed water surface elevations for different discharge in Tigris and Diyala Rivers with discharge of $5 \mathrm{~m}^{3} \mathrm{~s}-1$ with calibration and verification data.

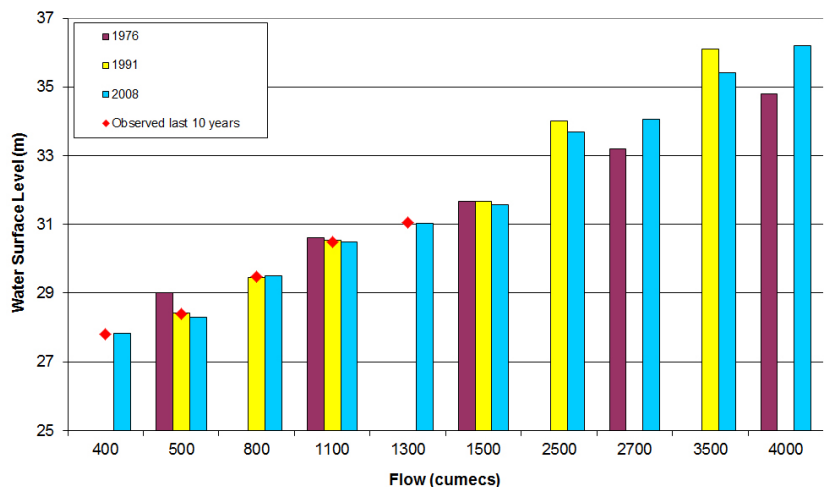

Fig. 13. Comparison for computed water levels at Sarai Baghdad station in 1976, 1991 and 2008.

inflow was also checked. The average differences in water surface elevation for each scenario compared with the base condition are shown in Table 3. These differences indicate that the lateral inflow exerted no significant influence during periods of higher discharges.

The water surface elevations computed at the Sarai Baghdad station from the present study are plotted against those from previous studies (Geohydraulique in 1977 and University of Technology in 1992) in Fig. 13. The more recent water level predictions are lower than those of the 1976 study for low discharges but higher than those for high discharge. They are always lower than the levels recorded in 1991.

The plots in Fig. 12 indicate that discharges that are higher than $2700 \mathrm{~m}^{3} \mathrm{~s}^{-1}$ could cause partial inundation in some areas in the northern part of the reach. The critical water surface elevation for inundation in the reach is $35 \mathrm{~m}$, at
Table 3. Average differences in water elevation (m) for each scenario with respect to base scenario.

\begin{tabular}{rrrr}
\hline $\begin{array}{r}\text { Tigris Flow } \\
\mathrm{m}^{3} \mathrm{~s}^{-1}\end{array}$ & Lat. Flow 25 & Lat. Flow 50 & Lat. Flow 100 \\
\hline 400 & 0.040 & 0.102 & 0.209 \\
500 & 0.038 & 0.087 & 0.186 \\
800 & 0.030 & 0.067 & 0.142 \\
1100 & 0.023 & 0.052 & 0.110 \\
1300 & 0.019 & 0.044 & 0.095 \\
1500 & 0.017 & 0.039 & 0.083 \\
2500 & 0.010 & 0.023 & 0.049 \\
2700 & 0.009 & 0.021 & 0.047 \\
3500 & 0.008 & 0.020 & 0.045 \\
4000 & 0.007 & 0.019 & 0.043 \\
\hline
\end{tabular}

station $43000 \mathrm{~m}$. For discharges greater than $3500 \mathrm{~m}^{3} \mathrm{~s}^{-1}$ the inundation could take place along approximately $9 \mathrm{~km}$ of the reach. For the southern part of the reach under examination, the inundation is not expected to occur below a discharge of $35000 \mathrm{~m}^{3} \mathrm{~s}^{-1}$.

The water surface slopes for the base condition varied from 6.03 to $6.84 \mathrm{~cm} \mathrm{~km}^{-1}$ for discharges between 400 and $1500 \mathrm{~m}^{3} \mathrm{~s}^{-1}$, respectively. For discharges of 2500 and $2700 \mathrm{~m}^{3} \mathrm{~s}^{-1}$, respectively the slopes were 8.59 and $8.96 \mathrm{~cm} \mathrm{~km}^{-1}$, but reached $10 \mathrm{~cm} \mathrm{~km}^{-1}$ for discharges of 3500 and $4000 \mathrm{~m}^{3} \mathrm{~s}^{-1}$.

The rating curve used to define the downstream boundary condition needs modification for the high water stages to give more reliable estimates of the new geometry conditions in the river. 


\section{Conclusions}

The results of the three surveys and the operation of the model on the channel of the Tigris indicate the following:

1. Recent shortages in the flow have kept the water levels low on all of the river cross-sections so that the protected banks have had little value for flood protection; however, they have helped the river to reach a new stable regime.

2. Since the water is now eroding below the protected bank levels this will lead to the collapse of parts of these banks in the future.

3. The variations in the level of the river bed were less in the 2008 survey than during the surveys of 1976 and 1991.

4. The average slope of the river bed was steeper in 2008 than during the earlier surveys.

5. The bed obstacles during the 2008 survey were greater in number and occupied the most complicated locations than during the two earlier surveys.

6. The output from the model showed very good coincidence with the observed water surface levels at the Sarai Baghdad station and also along the lower $15 \mathrm{~km}$ of the reach examined.

7. The computed water surface slopes varied from 6.03 to $6.84 \mathrm{~cm} \mathrm{~km}^{-1}$ during low flow conditions.

8. Inundation could take place along approximately $9 \mathrm{~km}$ of the reach surveyed with discharges greater than $3500 \mathrm{~m}^{3} \mathrm{~s}^{-1}$.

Acknowledgements. The authors would like to express their thanks to Baghdad University for sponsoring the first author with a grant. The research presented was carried out as a part of "Swedish Hydropower Centre - SVC". SVC has been established by the Swedish Energy Agency, Elforsk and Svenska Kraftnät together with Luleå University of Technology, The Royal Institute of Technology, Chalmers University of Technology and Uppsala University; www.svc.nu.

Edited by: G. Di Baldassarre

\section{References}

Al-Ansari, N. A. and Knutsson, S.: Toward Prudent management of Water Resources in Iraq, J. Advanced Science and Engineering Research, 1, 53-67, 2011.

Al-Ansari, N. A. and Toma, A.: Bed characteristics of the River Tigris within Baghdad, J. Water Res., 3, 1-23, 1984.

Al-Ansari, N. A., Ali, S. H., and Taqa, A. S.: Sediment discharge of the River Tigris at Baghdad (Iraq), Proceedings of the Canberra Symposium, IAHS-AISH P., 128, 399-407, 1979.

Al-Ansari, N. A., Sayfy, A., Al-Sinawi, G. T., and Ovanessian, A. A.: Evaluation of the water quality for the lower reaches of River Tigris using multivariate analysis, J. Water Res., 5, 173-187, 1986.

Al-Ansari, N. A., Salman, H. H., and Al-Sinawi, G. T.: Periodicity of selected water quality parameters for the Tigris water at Baghdad, J. Water Res., 6, 11-17, 1987.

Al-Shahrabaly, Q. M.: River discharges for Tigris and Euphrates gauging stations, Ministry of Water Resources, Baghdad, 2008.

Encyclopaedia Britannica: available at: http://www.britannica.com/ EBchecked/media/2034/Iraq, last access: 22 December 2010.

Geohydraulique: Tigris River training project within Baghdad City, report submitted to the Ministry of Irrigation-Iraq, Paris, 1977.

Herza Engineering Company: Hydrological survey of Iraq, report submitted to the Ministry of Agriculture-Iraq, Illinois, 1963.

Korpak, J.: The influence of river training on mountain channel changes (Polish Carpathian Mountains), Geomorphology, 92, 166-181, 2007.

Lammersen, R., Engel, H., van de Langemheen, W., and Buiteveld, H.: Impact of river training and retention measures on flood peaks along the Rhine, J. Hydrol., 267, 115-124, 2002.

Marchi, E., Roth, G., and Siccardi, F.: The Po: Centuries of River Training, Phys. Chem. Earth, 20, 475-478, 1996.

Morris, G. L. and Fan, J.: Reservoir Sedimentation Handbook, McGraw Hill Book Co., New York, 2010.

NEDECO: Study of the navigation in Tigris River between Baghdad and Mosul, report submitted to the Ministry of Development, Amsterdam, 1958.

University of Technology: Training of Tigris River inside Baghdad City, report submitted to the Ministry of Agriculture and Irrigation-Iraq, Baghdad, 1992. 